\title{
Isolation and Identification of Bacteria from Chlorpyrifos Polluted Soil
}

\author{
M. Santhoshkumar, T. Mahakavi and L. Baskaran* \\ Department of Botany, Annamalai University, Annamalai nagar, India- 608002. \\ E-mail address: santhoshphd2016@gmail.com
}

Keywords: Chlorpyrifos, Bacillus subtilis, Pseudomonas putida, Pseudomonas aeruginosa.

\begin{abstract}
The present study aimed to isolate and identify the chlorpyrifos resistant soil bacteria from contaminated soils in order to be used for bioremediation of polluted environments. Bacteria were isolated from two cultivated plant root rhizopheric soil of Cocks comb (Celosia cristata) and Marigold (Tagetes erecta). The pesticide was tested at 5 elevated doses, $0.5 \%, 1 \%, 2 \%, 2.5 \%$ and control. Physiochemical properties of soils, $\mathrm{P}^{\mathrm{H}}$, Electrical conductivity, Organic carbon, Organic matter, Nitrogen, phosphorus, potassium, Manganese and Iron were analyzed. Based on morphological and biochemical tests the isolates were identified as Bacillus subtilis, Pseudomonas putida, Pseudomonas aeruginosa. Thus, the organisms can be exploited for bioremediation of chlorpyrifos polluted soil, and their ability to degrade other organophosphates pesticide.
\end{abstract}

\section{INTRODUCTION}

Soil plays an important role in resolve the quality and composition of biosphere which develops over it. Soils contain biological, chemical and physical features maintaining the functions of both natural and managed ecosystems, and sustainable agricultural fertility and productivity (Pankhurst et al., 1997; Enriqueta-Arias et al., 2005). Soil biota, including flora, fauna and microorganisms, perform functions that help to the soil's development, structure and productivity. The indigenous microbial populations in soil are of fundamental importance for ecosystem, function through determining, nutrient cycling, and decomposition and energy flow. Bacteria are considered to be very important for soil fertility. The variation in bacterial population may be caused nutritional and environmental changes, chemical pollution etc. Any adverse impact of chemical on soil characteristics and microorganism may lead to ultimate loss of soil fertility (Ubuoh et al., 2012). The modern pesticides are in use all over the world. Among the modern pesticides, systemic pesticides are being widely used in agriculture. Approximately $90 \%$ of agricultural pesticide application never reaches its target organisms but is, instead, dispersed through the air, soil, and water (Moses et al. 1993). In addition, many soil-applied pesticides are also intentionally introduced into the soil environment for the control of soil borne pests and pathogens, which results in the accumulation of their residues and metabolites in soil at unacceptably high levels (Redondo et al. 1997; Gamo' n et al. 2003).

Chlorpyrifos(o,o-diethyl o-(3,5,6-trichloro-2-pyridyl) phosphorothioate, is a broad spectrum, organophosphorus insecticide, used for the control of a wide range of pests such as cutworms, corn rootworms, cockroaches, grubs, flea beetles, flies, termites, fire ants, aphids, lice, leptinotarsa and other insects. The environmental fates of the major chlorpyrifos degradate, 3, 5, 6-trichloro-2pyridinol (TCP), indicate that it is mobile in soils and persistent in soils when not exposed to light. Chlorpyrifos may persists in environment up to one year (half-life of 60-120 days), have low water solubility $(2 \mathrm{mg} / \mathrm{L})$ and soluble in organic solvents. Several studies on widely-used pesticides have already shown that pesticide application leads to changes in soil nutrient levels and alterations to soil microbial activity, diversity and genetic structure (Monkiedje et al., 2002; Ros et al., 2006). The soil Pollutants may also affect the bacterial composition and diversity and can have significant impact on the functioning of multiple components of the soil ecosystem (Wan et al., 2014).The present study aimed to investigate the effect of chlorpyrifos on soil bacterial diversity. 


\section{MATERIALS AND METHODS}

\section{Pot culture Experiment:}

This experiment was conducted using soils with two plants namely, Cocks comb (Celosia cristata) and Marigold (Tagetes erecta). Experiment was carried out at Annamalai University, Botanical garden. Cultivation took place in plastic pots. Five sets $(20$ pot $\times 5)$ of pots were prepared, two sets, one for the Cocks comb and the other for the Marigold. The soils were subjected to different dose of pesticide concentration Control, $0.5 \%, 1 \%, 2 \%$, and $2.5 \%$. Plant seeds were inserted, and the pots were irrigated to a level equal to the field capacity for each soil. After treatment, plant root rhizospheric soil samples were collected at $30^{\text {th }}$ days. These samples were homogenized and spread in trays to be cleaned of extraneous materials (pieces of root, leaves, small stems, etc.) and stored in plastic containers for further experiment.

\section{Soil analysis:}

Physiochemical properties of the experimental soils were characterized. Physicochemical analyses all of which were determined using the standard procedures included soil $\mathrm{pH}$, electrical conductivity (EC), organic carbon, and organic matter, total nitrogen (Subbiah and Asija, 1956), available phosphorus, Available potassium (Jackson, 1958), Available Manganese, iron (Piper, 1966).

\section{Isolation, Identification and Population counting:}

The soil samples are collected from root rhizospheric of plants, also chlorpyrifos-free soil Samples were collected as controls. For Population counting one gram of soil sample (Chlorpyrifos contaminated as well as control) was placed in a test tube containing $9 \mathrm{ml}$ sterilized distilled water .Soil suspensions were subjected to sequential dilution up to $10^{-6}$ to get reasonable count/plate. The $0.1 \mathrm{ml}$ each of the dilutions was added to each of the three sets of agar based petriplates having nutrient agar medium. After inoculation, plates were incubated at $28 \pm 2^{\circ} \mathrm{c}$ for 48 hours. At the end of incubation the plates were taken for enumeration of colonies present on the Petri plates and the population of different soil bacteria was calculated and expressed in terms of colony forming unit (CFU) per gram of the soil. Identification of the three different bacterial isolates was carried out by the routine bacteriological methods i.e., by the colony morphology (Size, shape, surface, opacity) biochemical tests like Gram staining, Starch hydrolysis, Motility, Oxidase, Catalase and Urease tests. Statistical significance was assessed at the $\mathrm{p}<0.05$ level using one way ANOVA and means were separated by Duncan's multiple range test $(p<0.05)$ with the help of SPSS 14 software package. Means and standard deviation were calculation from 3 replications.

\section{RESULT AND DISCUSSION}

The physicochemical properties of soil samples were presented in Table 1.Significantly $\mathrm{P}^{\mathrm{H}}$ (7.2) increase at $2.5 \%$ treated soil. When compared with control (6.8) soil.

Table 1: Physical-chemical properties of pesticide polluted soils.

\begin{tabular}{|c|c|c|c|c|c|c|c|c|c|}
\hline $\begin{array}{l}\text { Treatment } \\
\text { Concentration }\end{array}$ & $\mathrm{P}^{\mathrm{H}}$ & $\begin{array}{c}\mathrm{EC} \\
\left(\mathrm{dsm}^{-1}\right)\end{array}$ & $\begin{array}{c}\text { Organic carbon } \\
(\%)\end{array}$ & $\begin{array}{r}\text { Organic } \\
(\%)\end{array}$ & $\begin{array}{l}\text { ter } \mathrm{N} \\
(\mathrm{mg} / \mathrm{kg})\end{array}$ & $\begin{array}{c}\mathrm{P} \\
(\mathrm{mg} / \mathrm{k}\end{array}$ & $\begin{array}{c}\mathrm{K} \\
(\mathrm{mg} / \mathrm{kg})\end{array}$ & $\begin{array}{c}\mathrm{Mn} \\
(\mathrm{mg} / \mathrm{kg})\end{array}$ & $\begin{array}{l}\text { Iron } \\
(\mathrm{mg} / \mathrm{g})\end{array}$ \\
\hline Control & 6.8 & 0.75 & 0.61 & 1.20 & 91 & 36 & 55 & 81 & 78 \\
\hline $2.5 \%$ & 7.2 & 0.49 & 0.45 & 1.09 & 61 & 19 & 27 & 59 & 60 \\
\hline
\end{tabular}

The results of bacterial count of rhizospheric soil are detailed in Fig 1. It was found that the highest bacterial density (CFU/g soil) in control $\left(74.1 \times 10^{6}\right.$ and $\left.72.8 \times 10^{6}\right)$ in both plant of cockscomb and marigold rhizospheric soils. Then the bacterial diversity was gradually declined 
$\left(68.3 \times 10^{6}, 57.0 \times 10^{6}, 41.2 \times 10^{6}, 35.1 \times 10^{6}\right.$ and $\left.65.1 \times 10^{6}, 54.8 \times 10^{6}, 39.2 \times 10^{6} 29.3 \times 10^{6}\right)$ with increasing the pesticide concentration $0.5 \%, 1 \%, 2 \%$ and $2.5 \%$ in cockscomb and marigold plant respectively. The same results were supported by following authors. Akhtar et al., 2004, reported that soil characteristics (soil type, organic matter content, and $\mathrm{pH}$ ) affect the abundance of soil microorganisms.

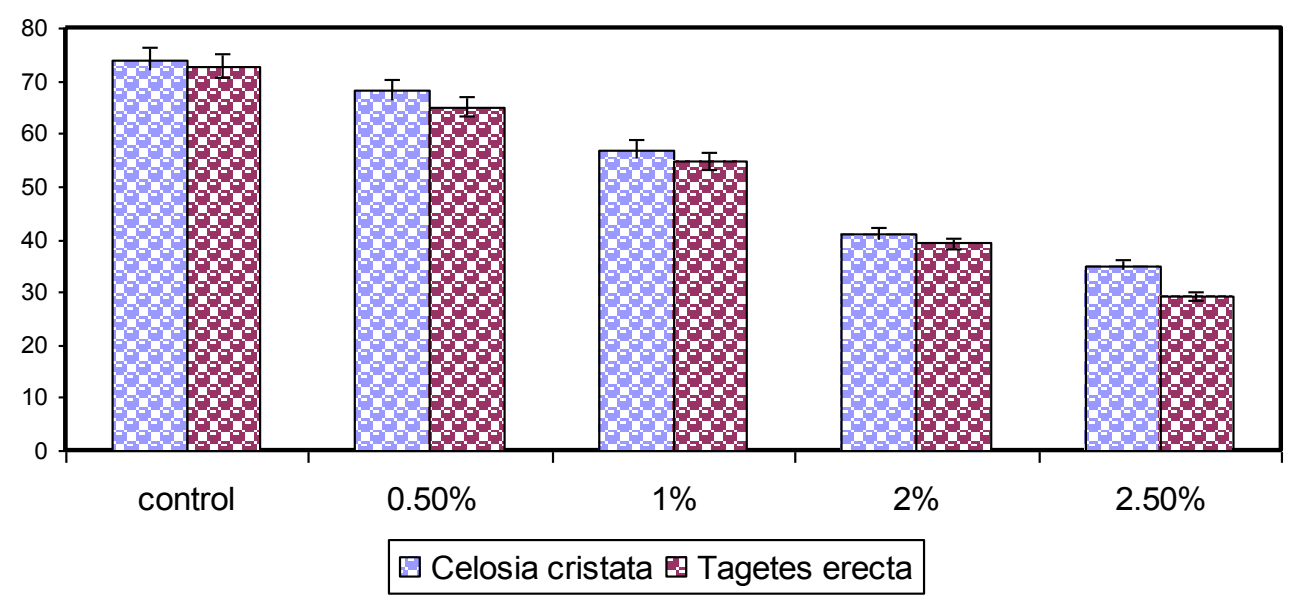

Fig. 1. Bacterial population in response to different Concentration of Pesticides in rhizospheric soil of Cocks comb and Marigold

Chlorpyrifos significantly reduced bacteria population in laboratory condition (Ahmed and Ahmed, 2006). Xinbin Zhou et al., 2012 also suggested that higher concentration Carbufuran and butachlor significantly inhibit the populations and activity of bacteria.

Table. 2. Morphological characterization of the bacterial isolates.

\begin{tabular}{|l|l|l|l|l|}
\hline \multicolumn{1}{|c|}{$\begin{array}{c}\text { Bacterial } \\
\text { isolates }\end{array}$} & \multicolumn{1}{|c|}{ Size } & Shape & Surface & Opacity \\
\hline Bacillus subtilis & Medium & Rods & Glistering & opaque \\
\hline $\begin{array}{l}\text { Pseudomonas putida } \\
\text { Pseudomonas } \\
\text { aeruginosa }\end{array}$ & Medium & Rods & Smooth & opaque \\
\hline
\end{tabular}

Table. 3. Biochemical characterization and identification of the bacterial isolates.

\begin{tabular}{|l|c|c|c|c|c|c|}
\hline & $\begin{array}{c}\text { Gram } \\
\text { staining }\end{array}$ & $\begin{array}{c}\text { Starch } \\
\text { hydrolysis } \\
\text { test }\end{array}$ & $\begin{array}{c}\text { Motility } \\
\text { test }\end{array}$ & $\begin{array}{c}\text { Oxidase } \\
\text { test }\end{array}$ & $\begin{array}{c}\text { Catalase } \\
\text { test }\end{array}$ & $\begin{array}{c}\text { Urease } \\
\text { test }\end{array}$ \\
\hline Bacillus subtilis & + & + & + & + & + & - \\
\hline Pseudomonas putida & - & + & + & - & - & - \\
\hline $\begin{array}{l}\text { Pseudomonas } \\
\text { aeruginosa }\end{array}$ & - & - & + & - & - & - \\
\hline
\end{tabular}

Based on morphological (Table-2) and biochemical tests (Table-3) the isolates were identified as Bacillus subtilis, Pseudomonas putida, and Pseudomonas aeruginosa. Latifi et al., 2011 was isolated two bacterial species from chlorpyrifos polluted soil they are, Pseudomonas aeruginosa, Pseudomonas putida. 


\section{CONCLUSION}

This study concludes that the isolated of three bacterial species, Bacillus subtilis, Pseudomonas putida and Pseudomonas aeruginosa that possess the capacity to tolerate and grow in the presence of high concentrations of the pesticide marks them out as good candidates for the bioremediation of chlorpyrifos polluted environment.

\section{References:}

[1] Ali Mohammad Latifi, Samaneh Khodi, Morteza Mirzaei, Mohsen Miresmaeili and Hamid Babavalian. Afri. Jour. of Biotech. 1(13) (2011) 3140-3146.

[2] Enriqueta-Arias, M., Gonzalez-Perez, J.A., Gonzalez-Vila, F.J., Ball, A.S 8 (2005)13-21.

[3] Gamo'n M., E Sa'ez E., Gil J., Boluda R. Arch. Environ. Contam. Toxicol. 44 (2003) 141151.

[4] Jackson, M.L., 1958. In: Soil Chemical Analysis. Prentice-Hall of India Private Limited, New Delhi.

[5] Moses M., Johnston E.S., Anger W.K., Burse V.W., Horstman S.W., Kackson R.J., Lewis R.G., Maddy K.T., McConnell R., Meggs W.J., Zahm S.H. Toxicol. Ind. Health. 9 (1993) 913-959.

[6] Monkiedje A. Ilori, M.O.Spiteller, M.Soil Biology \& Biochemistry. 34 (2002) 1939-1948.

[7] Pankhurst, C.E., Doube, B.M., Gupta, V.V.S.R., 1997. Biological indicators of soil health. Synthesis. In: Pankhurst, C.E., Doube, B.M., Gupta, V.V.S.R. (Eds.), Biological Indicators of Soil Health. CABI Publishing, Wallingford, UK, pp. 419-435.

[8] Piper, C., 1966. Soil and plant analysis.Asian Hans Publishers, Bombay, pp. 11-36.

[9] Redondo M.J., Ruiz M.J., Font G., Boluda R. Arch. Environ. Conta. Toxicol. 32 (1997) 346352.

[10] Ros, M., Goberna, M. Moreno, J.L. Hernandez, Akhtar S, Gilani S T S, Hasan N.. Pakistan Journal of Botany. 36(4) (2006) 863-870.

[11] Shail Ahmed and Muhammed Shakeel Ahmed, Pak. Entomol. 34 (2) (2006) 63-67.

[12] Subbiah, B.V. and Asija, G.LA rapid procedure for the determination of available nitrogen in soils. Curr. Sci. 25 (1956) 259-60.

[13] Ubuoh, E.A., Akhionbare, S.M.O. and Akhionbare, W.N..Inter. Jur. Multidisciplinary Sci. \& Engin. 3(2) (2012) 34.

[14] Wan, R.,Wang, Z., Xie, S. Science of the Total Environment. 472 (2014) 502-508.

[15] Xinbin Zhou, Xiaojun Shi, Lamei Zhang and Yongxiang Zhou. Energy Procedia 16 (2012)284- 289. 